\title{
UPAYA MENINGKATKAN MOTIVASI DAN HASIL BELAJAR SISWA MELALUI MODEL QUANTUM LEARNING PADA MATA PELAJARAN IPA MATERI PENYESIAIAN DIRI MAKHLUK HIDUP KELAS V SD MUHAMMADIYAH BAUSASRAN YOGYAKARTA
}

\author{
Hendi Dwi Cahyo, Ika Maryani \\ Universitas Ahmad Dahlan \\ hendy.cahyo07@gmail.com
}

\begin{abstract}
The material taught at this time is increasingly difficult, the way to teach teachers is still conventional, the lack of media and learning facilities, especially in science learning which requires concrete understanding. This study aims to improve motivation and learning outcomes in science lessons through Quantum Learning for fifth grade students at SD Muhammadiyah Bausasran. The subjects in this study were fifth grade students of SD Muhammadiyah Bausasran. The object in this study is the motivation and learning outcomes of science using the Quantum Learning model. Data collection techniques used in the form of observation, tests, and interviews. While the analysis technique uses descriptive quantitative. The research carried out belongs to the type of Class Action Research which consists of two cycles. The criteria for success of action in this study are seen from the increase in motivation and learning outcomes of science using Quantum Learning. The results showed that the activities and learning outcomes of science used Quantum Learning models from cycle I and Cycle II experienced an increase. The results of observation of motivation of students in the first cycle of the first meeting the percentage value of $35.33 \%$ reached the criteria of "low", the second meeting obtained a percentage of $45.44 \%$ which reached the criteria of "sufficient". In the second cycle the first meeting percentage was $68.76 \%$ and reached the criteria of "high" while the second meeting received a percentage of $93.95 \%$ with the criteria of "very high". Whereas in the learning outcomes of students of science subjects using the Quantum Learning model based on the results of the pretest and posttest conducted the results obtained in the first cycle the percentage completeness of the class from the first cycle of the first meeting was $8.33 \%$, while the second meeting was $33.33 \%$. In the second cycle the first meeting became $79.17 \%$ and at the second meeting it became 95.83\%. The results of the percentage of completeness have reached the completeness value $>70 \%$.
\end{abstract}

Keywords: Motivation, Learning, Outcomes, Quantum Learning 


\begin{abstract}
ABSTRAK
Materi yang diajarkan saat ini semakin sulit, cara mengajar guru masih konvensional, kurangnya media dan fasilitas pembelajaran terutama dalam pembelajaran IPA yang membutuhkan pemahaman secara konkret. Penelitian ini bertujuan untuk meningkatkan motivasi dan hasil belajar pada pelajaran IPA melalui Quantum Learning bagi siswa kelas V di SD Muhammadiyah Bausasran. Subjek dalam penelitian ini adalah siswa kelas V SD Muhammadiyah Bausasran. Objek dalam penelitian ini adalah motivasi dan hasil belajar IPA menggunakan model Quantum Learning. Teknik pengumpulan data yang digunakan berupa observasi, tes, dan wawancara. Sedangkan teknik analisis menggunakan deskriptif kuantitatif. Penelitian yang dilakukan termasuk ke dalam jenis Penelitian Tindakan Kelas yang terdiri atas dua siklus. Kriteria keberhasilan tindakan dalam penelitian ini dilihat dari peningkatan motivasi dan hasil belajar IPA menggunakan Quantum Learning. Hasil penelitian menunjukkan bahwa aktivitas dan hasil belajar IPA menggunakan model Quantum Learning dari siklus I dan Siklus II mengalami peningkatan. Hasil observasi motivasi siswa pada siklus I pertemuan pertama nilai presentase sebesar $35,33 \%$ mencapai kriteria "rendah", pertemuan kedua memperoleh presentase sebesar 45,44\% yang mencapai kriteria "cukup". Pada siklus II pertemuan pertama presentase sebesar 68,76\% dan mencapai kriteria "tinggi" sedangkan pertemuan kedua memperoleh persentase sebesar 93,95\% dengan kriteria "sangat tinggi". Sedangkan pada hasil belajar siswa mata pelajaran IPA menggunakan model Quantum Learning berdasarkan hasil pretest dan postest yang dilakukan didapat hasil pada siklus I presentase ketuntasan kelas dari siklus I pertemuan pertama sebanyak $8,33 \%$, sedangkan pertemuan kedua sebanyak 33,33\%. Pada siklus II pertemuan pertama menjadi $79,17 \%$ dan pada pertemuan kedua menjadi 95,83\%. Dari hasil presentase ketuntasan sudah mencapai nilai ketuntasan $>70 \%$.
\end{abstract}

Kata kunci: Motivasi, Hasil Belajar, Quantum Learning

\title{
PENDAHULUAN
}

Proses pembelajaran di Sekolah Dasar adalah pembelajaran konkrit, yaitu suatu pembelajaran yang dilaksanakan secara logis dan sistematis serta pembelajaran yang mengarah kepada hal yang menyenangkan, pembelajaran yang memperhatikan kejadian atau peristiwa yang ada di lingkungan sekitar siswa. Karenanya pembelajaran yang bersifat konkrit dan menyenangkan lebih sesuai bila diberikan kepada siswa Sekolah Dasar. Kondisi seperti ini harus diupayakan agar kemampuan siswa, proses belajar siswa, sesuai dengan tahapan perkembangan siswa. Pembelajaran yang konkrit dan menyenangkan ini jug amempengaruhi motivasi dan hasil belajar siswa. Hasil penilaian seharusnya dapat memotivasi belajar siswa, dan dapat menjadi pembimbing bagi siswa untuk belajar, bagi siswa yang memperoleh hasil penilaian kurang baik seharusnya menjadi dorongan untuk lebih berhasil dalam kegiatan penilaian yang akan datang dan secara tepat dapat mengetahui diwilayah mana terletak kelemahannya. Bagi siswa yang memperoleh hasil yang baik tentu saja hasil itu dapat menjadi motivasi mempertahankan dan meningkatkan hasilnya, serta menjadi pedoman dalam mempelajari bahan pengayaan. Selain mendorong siswa untuk belajar lebih baik, dengan adanya penilaian juga dapat mendorong guru untuk lebih baik lagi cara yang khas/khusus, yaitu melakukan obesrvasi eksperimentasi, penyimpulan, 
penyusunan teori, eksperimentasi, obeservasi dan demikian seterusnya kait-mengkait antara cara yang satu dengan cara yang lain. (Aly, 2013). Pendidikan IPA diharapkan lebih menjadi mata pelajaran yang mengasikan bagi siswa untuk mempelajari diri sendiri maupun alam sekitar. Proses pembelajaran IPA menekankan pada pemberian pengalaman langsung untuk mengembangkan kompetensi agar mampu memahami alam sekitar secara ilmiah. Serta di dalam IPA haruslah disisipkan proses pembelajaran yang mampu membuat siswa lebih aktif dan membawa suasana di ruang kelas menjadi menyenangkan, sehingga dapat menunjang kualitas pendidikan.

Upaya meningkatkan kualitas pendidikan yang baik, guru perlu menciptakan suasana belajar yang terkait langsung dengan konteks pengalaman kehidupan nyata. Untuk mencapai keberhasilan proses pembelajaran, seorang guru dituntut untuk dapat memilih dan menggunakan metode pembelajaran yang sesuai dengan bahan ajar yang akan diberikan kepada siswa. Guru mampu menciptakan pembelajaran yang konkrit dan menyenangkan sehingga siswa aktif di kelas. Berdasarkan kenyataannya banyak masalah yang terjadi dalam proses pembelajaran di kelas. Permasalahan tersebut terjadi pada siswa kelas V di SD Muhammadiyah Bausasran Yogyakarta. Hasil pengamatan yang dilakukan pada bulan Agustus 2016 diperoleh data diantaranya adalah kurangnya motivasi dan semangat siswa dalam mengikuti pembelajaran IPA berlangsung.Hal ini disebabkan karena guru kurang bervariasi dalam menggunakan metode dan model yang mampu menarik perhatian siswa, kurangnya terlibatnya siswa secara langsung dalam proses pembelajaran sehingga IPA dianggap mata pelajaran yang sulit, dan cenderung siswa merasa bosan ketika pembelajaran IPA, sehingga ketika kegiatan pembelajaran yang berlangsung masih belum bias membangkitkan semangat maupun menghidupkan suasana diruang kelas yang menyenangkan.Hal ini, memberi dampak pada rendahnya hasil belajar siswa dan kurang optimal, karena pada saat dilakukan pengamatan masih banyak nilai siswa yang belum memenuhi Kriteria Ketuntasan Minimal (KKM).

Hasil belajar siswa dapat dilihat dari nilai ulangan harian pada mata pelajaran IPA masih banyak siswa yang di bawah KKM, berdasarkan wawancara pada tanggal 22 Mei 2017 dengan guru wali kelas V SD Muhammadiyah Bausasran bahwa siswa masih kurang termotivasi dan berdampak pada hasil belajar siswa pada mata pelajaran IPA yang rata-rata nilainya masih di bawah KKM yaitu 75 . Berdasarkan hasil ulangan harian siswa 57\% masih dibawah KKM. Hal ini dapat dilihat dari 21 siswa yang tuntas hanya 9 sedangkan 12 siswa masih dibawah KKM. Dapat dilihat bahwa masih ada beberapa siswa yang nilai nya di bawah KKM, selain itu, ketika melakukan wawancara dengan guru kelas $\mathrm{V}$ bahwa nilai IPA rendah dikarenakan materi yang sulit disampaikan dengan siswa dan perlu adanya inovasi dalam pembelajaran. Salah satu dari sekian upaya yang dapat dilakukan guru untuk meningkatkan motivasi dan hasil belajar serta kegiatan yang menyenangkan adalah dengan menggunakan model-model yang lebih menarik dan lebih mengaktifkan siswa. Salah satunya adalah dengan menggunakan model Quantum Learning. Quantum Learning merupakan pengubahan belajar yang meriah ataupun menyenangkan, dengan segala nuansanya. Quantum Learning juga menyertakan segala kaitan antara, interaksi,dan perbedaan yang memaksimalkan momen belajar. Quantum Learning berfokus pada hubungan dinamis pada lingkungan kelas, interaksi yang mendirikan landasan dan kerangka untuk belajar (Sohimin, 2014).

Adapun karakteristik dari Quantum learning pada prinsipnya adalah bahwa sugesti dapat dan pasti mempengaruhi hasil situasi belajar, dan setiap detail apa pun memberikan sugesti positif ataupun negatif. Beberapa teknik yang digunakannya untuk

memberikan sugesti positif adalah mendudukan murid dengan nyaman, memasang musik latar dalam kelas, meningkatkan partisipasi individu, menggunakan poster-poster untuk memberikan kesan besar sambal menunjukkan informasi, dan menyediakan guru-guru 
yang terlatih baik dalam seni pengajaran sugestif (Deporter, 2016). Berdasarkan karakteristik dari model pembelajaran Quantum Learning, maka salah satu konsep yang cocok untuk diterapkan dengan model Quantum Learning adalah pada mata pelajaran IPA kelas V SD. Peneliti mengamati bahwa siswa kelas V dalam memahami konsep dalam mata pelajaran IPA perlu pembelajaran yang konkrit dan nyata serta menyenangkan. Dengan peneliti menggunakan model Quantum Learning ini diharapkan siswa semakin berantusias, berrfikir lebih kreatif, mengeksplor pemahaman lebih mendalam. Dimana kelak akan mampu meningkatkan hasil belajar siswa dalam mata pelajaran IPA.

Berdasarkan latar belakang masalah yang telah peneliti uraikan di atas, maka peneliti akan menerapkan Model Pembelajaran Quantum Learning Sebagai Upaya Meningkatkan Motivasi dan Hasil Belajar Siswa dalam Mata Pelajaran IPA Kelas V SD Muhammadiyah Bausasran Yogyakarta." Berdasarkan latar belakang yang telah diuraikan di atas maka dapat diperoleh rumusan masalahnya dalam penelitian sebagai berikut: Bagaimana peningkatan motivasi dan hasil belaar IPA dengan menggunakan model Quantum Learning pada siswa kelas V SD Muhammadiyah Bausasran Yogyakarta? Sesuai dengan rumusan masalah yang telah disebutkan, maka dapat diperoleh tujuan penelitian adalah untuk mengetahui peningkatan motivasi dan hasil belajar IPA dengan menggunakan model Quantum Learning pada siswa kelas V SD Muhammadiyah Bausasran Yogyakarta.

\section{METODE PENELITIAN}

Peneleitian ini merupakan jenis penelitian tindakan kelas (classroom action research). Dalam penelitian ini dilakukan dalam 2 Siklus dengan 4 kali pertemuan pembelajaran. Disetiap siklusnya dilaksanakan 1-2kali pertemuan pembelajaran. Penelitian ini dilaksanakan di SD Muhammadiyah Bausasran Yogyakarta yang beralamat di Jl. Ronodigdayan No. 60 Kelurahan Bausasran, Kecamatan Danurejan Kota Yogyakarta yang merupakan SD terpadu gabungan dari SD Muhammadiyah Bausasran 1, dan SD Muhammadiyah Bausasran. Yang memiliki 12 kelas dan memiliki 2 rombel. Penelitian ini akan dilaksankan pada bulan Juli 2017 pada siswa kelas V.

Subjek dalam penalitian ini adalah siswa SD Muhammadiyah Bausasran 2 Yogyakarta. Lembaga pendidikan tersebut mempunyai enam kelas maka peneliti akan mengambil ruang sampel salah satu kelas yang mewakili. Jenjang yang dipilih adalah komunitas siswa kelas V yang berjumlah 24 orang dengan 13 perempuan dan 11 laki-laki. Teknik pengumpulan data merupakan teknik atau cara yang digunakan peneliti untuk mendapatkan data. Data dalam penelitian ini diperoleh menggunakan beberapa teknik pengumpulan data yaitu observasi, tes dan wawancara. Penelitian ini menggunakan teknik pengumpulan data berupa observasi, tes dan wawancara dengan menggunakan instrumen berupa lembar observasi, hasil tes dan pedoman wawancara yang digunakan untuk mengumpulkan data. Data yang diperoleh dianalisi menggunakan metode deskriptif kuantitatif. Data kuantitatif adalah data berupa angka-angka yang digunakan untuk menganalisis hasil tes dan observasi siswa. Sedangkan deskriptif adalah data yang menentukan dan menafsirkan data yang ada dalam bentuk deskripsi dari hasil observasi guru dan wawancara.

Lembar observasi dalam penelitian ini meliputi lembar observasi penerapan modelQuantum Learning oleh guru dalam proses pembelajaran di kelas sebagai upaya meningkatkan motivasi dan hasil belajar, lembar observasi kegiatan yang dilakukan siswa selama pembelajaran dengan model Quantum Learning berlangsung. Melalui data lembar observasi motivasi belajar siswa kemudian dicari presentase dengan rumus menurut (Sudjana, 2012)seperti berikut:

Keterangan:

$$
\mathrm{P}=\frac{f}{N} x 100
$$

$\mathrm{P}=$ Angka presentasi motivasi belajar 
$\mathrm{F}=$ Frekuensi yang muncul

$\mathrm{N}=$ Banyaknya individu

Hasil dari Analisis data yang diperoleh akan dikonversikan menggunakan kriteria menurut Arikunto dan Safrudin (2009:35) sebagai berikut:

Tabel 1. Interval Skor

\begin{tabular}{cc}
\hline Interval Skor & Kriteria \\
\hline$<21$ & Rendah Sekali \\
\hline $21-40$ & Rendah \\
\hline $41-60$ & Cukup \\
\hline $61-80$ & Tinggi \\
\hline $81-100$ & Tinggi Sekali \\
\hline
\end{tabular}

Menurut Aqib (2014: 205) adapun rumus yang digunakan untuk mengetahui ketuntasan belajar siswa sebagai berikut:

$$
\mathrm{TBK}=\frac{k}{N} x 100 \%
$$

Keterangan:

TBK = Tuntas belajar klasikal

$\mathrm{K}=\Sigma$ siswa yang tuntas belajar

$\mathrm{N} \quad=$ Jumlah Siswa

Kriteria keberhasilan tindakan merupakan rumusan yang dijadikan acuhan dalam menentukan keberhasilan didalam penelitian. Untuk mengukur keberhasilan dalam penelitian ini adalah 1) Motivasi belajar siswa merupakan salah satu patokan keberhasilan penelitian ini. Motivasi belajar siswa dapat diperoleh dalam observasi penelitian dan dikatakan berhasil jika diperoleh persentase siswa yang motivasinya tinggi yaitu sebanyak $70 \%$. 2) Hasil belajar siswa melalui hasil pretest dan posttest. Hasil belajar siswa dapat dikatakan berhasil, apabila presentase siswa yang tuntas diatas KKM sebanyak $70 \%$.

\section{HASIL DAN PEMBAHASAN}

Pelaksanaan Penelitian Tindakan Kelas (PTK) dengan judul "Upaya Meningkatkan Motivasi dan Hasil Belajar Siswa Melalui Model Quantum Learning pada Mata Pelajaran IPA Kelas V SD Muhammadiyah Bausasran Yogyakarta" telah selesai dilaksanakan. Penelitian dilaksanakan dari tanggal 11 September 2017 sampai 18 september 2017 dengan 2 siklus.

Proses pengambilan data dilakukan pada mata pelajaran IPA menggunakan model Quantum Learning yang dilaksanakan secara kolaborasi dengan guru kelas sebagai pengajar dan peneliti sebagai observer selama proses pembelajaran. Kegiatan observasi dibantu oleh 3 orang mahasiswa lain sebagai pengamat motivasi yang terjadi di kelas. Materi yang digunakan dalam penelitian diambil berdasaran Standar Kompetensi yaitu mengidentifikasi cara makhluk hidup menyesuaikan diri dengan lingkungan.

Berdasarkan hasil observasi siswa yang dilakukan selama proses pembelajaran IPA menggunakan model Quantum Learning di kelas V dapat dikatakan hasilnya mengalami peningkatan mulai dari siklus I, sampai akhirnya pada siklus II. Berikut dapat dilihat perbandingan hasil observasi siswa yang dilakukan mulai dari siklus I, dan siklus II pada tabel dibawah ini:

Tabel 2. Perbandingan Hasil Observasi Motivasi Siswa

\begin{tabular}{lcccc}
\hline \multirow{2}{*}{ Keterangan } & Siklus I & \multicolumn{3}{c}{ Siklus II } \\
\cline { 2 - 5 } & P1 & P2 & P1 & P2 \\
\hline Jumlah siswa & 24 & 23 & 24 & 24 \\
\hline
\end{tabular}




\begin{tabular}{lrrrr}
\hline $\begin{array}{l}\text { Tata-rata Presentase } \\
\text { Motivasi }\end{array}$ & & & & \\
\hline Belajar Kriteria & rendah & cukup & tinggi & $93,95 \%$ \\
\hline
\end{tabular}

Berdasarkan diatas dapat dikatakan bahwa motivasi dari pembelajaran model Quantum Learning yang dilakukan siswa mengalami peningkatan dan tindakan berhasil dilakukan. Model Quantum Learning cukup cocok untuk meningkatkan motivasi siswa karena siswa diajak untuk melakukan berbagai proses pembelajaran yang menyenangkan, meriah, dan memaksimalkan momen belajar. Dengan belajar yang menyenangkan serta meriah siswa dapat termotivasi lagi dalam proses belajar.

Berdasarkan hasil tindakan dari siklus I dan siklus II pada pembelajaran IPA menggunakan model Quantum Learning pada materi mengidentifikasi penyesuaian diri makhluk hidup dengan lingkungan sekitar atau adaptasi menunjukkan adanya peningkatan kemampuan siswa dalam mengerjakan test yang diberikan. Terlihat dari hasil pretest dan postest pada siklus I yang awalnya banyak siswa yng tidak tuntas sedikit meningkat pada hasil postest. Pada siklus II mengalami peningkatan dilihat dari hasil postet siklus II jika dibandingkan dengan postest siklus I jumlah siswa yang tuntas mengalami peningkatan dilihat dari hasil postet siklus II jika dibandingkan dengan postest siklus I jumlah siswa yang tuntas mengalami peningkatan.

Tabel 3. Peningkatan Hasil Belajar Siswa pada Siklus I, II

\begin{tabular}{|c|c|c|c|c|c|}
\hline \multirow{3}{*}{ Keterangan } & \multirow[b]{3}{*}{ Pretest } & \multicolumn{2}{|c|}{ Siklus I } & \multicolumn{2}{|c|}{ Siklus II } \\
\hline & & Postest & Postest & Postest & Postest \\
\hline & & $P .1$ & P. 2 & $P .1$ & P. 2 \\
\hline Jumlah Siswa & 24 & 24 & 23 & 24 & 24 \\
\hline Rata- Rata Kelas & 22,33 & 60 & 69,74 & 77,92 & 90,42 \\
\hline Nilai Tertinggi & 40 & 75 & 90 & 90 & 100 \\
\hline Nilai Terendah & 10 & 30 & 30 & 40 & 65 \\
\hline Siswa Tuntas & 0 & 2 & 8 & 19 & 23 \\
\hline Siswa Tidak Tuntas & 24 & 22 & 16 & 5 & 1 \\
\hline Persentase Ketuntasan & 0 & $8,33 \%$ & $33,33 \%$ & $79,17 \%$ & 95,83 \\
\hline
\end{tabular}

Berdasarkan keseluruhan data yang didapat mulai dari siklus I pertemuan 1 dan 2 dan siklus II pertemuan I dan 2 indikator keberhasilan dicapai pada siklus II yaitu dengan presentase rata-rata kelas mencapai $90,42 \%$ dengan presentase nilai siswa yang tuntas sbesear $95,83 \%$.

\section{SIMPULAN}

Berdasarkan penelitian dapat disimpulkan bahwa terdapat peningkatan terhadap motivasi dan hasil belajar mata pelajaran IPA menggunakan model Quantum Learning pada kelas V SD Muhammadiyah Bausasran tahun ajaran 2017/2018 pada KD pertama Mengidentifikasi penyesuaian diri hewan dengan lingkungan tertentu untuk mempertahankan hidup dan KD kedua Mengidentifikasi penyesuaian diri tumbuhan dengan lingkungan tertentu untuk mempertahankan hidup, hal ini dapat dilihat di bawah ini:

Berdasarkan hasil observasi motivasi yang dilakukan siswa selama pembelajaran mulai dari siklus I dan siklus II terdapat peningkatan, dapat dilihat dari hasil pada siklus I dengan pertemuan ke-1 jumlah yang diperoleh 854,3 , presentase sebesar 35,33\%, dan mencapai kriteria "rendah" sedangkan pertemuan ke-2 diperoleh jumlah 1045,2, presentase sebesar 45,44\% dan mencapai kriteria "cukup". Pada siklus II dilaksanakan pertemuan ke1 diperoleh hasil jumlah mencapai 1650,3, presentase sebesar 68,76\% dan mencapai 
kriteria "tinggi", sedangkan pertemuan ke-2 diperoleh jumlah mencapai 2254,8, presentase sebesar 93,95\% dengan kriteria "tinggi sekali".

Model Quantum Learning dapat meningkatkan hasil belajar siswa, dapat terlihat pada hasil pretest dan postest yang dilakukan pada mata pelajaran IPA kelas V, dengan hasil Rata - rata kelas yang diperoleh pada siklus I pertemuan ke-1 adalah 60 sedangkan pertemuan ke-2 adalah 69,74 di siklus II pertemuan ke-1 menjadi 77,92 dan pertemuan ke2 menjadi 90,42. Sehingga menghasilkan presentase rata-rata kelas dari siklus I pertemuan ke-1 sebanyak 59,58\%\%, pada petemuan ke-2 menjadi 69,74\%. pada siklus II pertemuan ke-1 menjadi $77,91 \%$ dan pada pertemuan ke-2 menjadi 90,42\%. Sedangkan untuk presentase ketuntasan diperoleh hasil pada siklus I pertemuan ke-1 sebesar 8,33\%, pertemuan ke-2 sebesar 33,33\% pada siklus II pertemuan ke-1 menjadi 79,17\% dan pada pertemuan ke-2 menjadi $95,83 \%$. Hasil presentase rata-rata kelas tindakan dikatakan berhasil karena persentase siswa yang tuntas diatas KKM $>75 \%$ terlihat pada siklus II pertemuan 1 dan 2 nilai presentase ketuntasan sebesar 79,91\% dan 95,83\%. Sehingga penelitian ini dapat dikatakan berhasil,

\section{DAFTAR PUSTAKA}

Aly, A. (2013). Ilmu Ilmiah Dasar. Jakarta: PT Bumi Aksara.

Deporter, B. (2016). Quantum Learning. Bandung: Kaifa.

Kunandar. (2013). Langkah Mudah Penelitian Tindakan Kelas Sebagai Pengembangan Profesi Guru. Jakarta: Rajawali Pers.

Sohimin, A. (2014). 68 Model Pembelajaran Inovatif dalam Kurikulum 2013. Yogyakarta: Ar-Ruzz Media.

Sudjana, N. (2012). Penilaian Hasil Proses Belajar Mengajar. Bandung: PT Remaja Rosdakarya.

Suharsimi. (2012). Penelitian Tindakan Kelas. Jakarta: PT Bumi Aksara. 